\title{
ENSAIOS
}

\section{O CEMITÉRIO DOS VIVOS. TESTEMUNHO E FICÇÃO}

\author{
ALFREDO BOSI \\ Universidade de São Paulo
}

\begin{abstract}
Resumo
O cemitério dos vivos de Lima Barreto é uma obra original, pois combina um testemunho nitidamente autobiográfico e o esboço de um romance. Os fragmentos narrativos projetam desejos e frustrações do autor trabalhados mediante a mesma prosa lúcida e realista do depoimento. A interrogação sobre o significado da loucura e a revolta contra o tratamento dado aos supostos "anormais" constituem momentos fortes da obra e guardam um valor histórico e existencial raro na literatura pré-modernista.
\end{abstract}

Palavras-chave

Lima Barreto; Literatura e psicologia; Literatura e psiquiatria; Testemunho.

\begin{abstract}
O cemitério dos vivos, by Lima Barreto, is an original work that combines a clearly autobiographic witness and the sketch of a novel. The narrative fragments project the author's desires and frustrations through the same lucid and realistic prose of the testimony. The inquiry regarding the meaning of madness and the rebellion against the treatment given to the so-called "abnormal" constitute the work's strong moments and assure a historical and existential value rare in pre-modernist literature.
\end{abstract}

Keywords

Lima Barreto; Literature and psychology; Literature and psychiatry; Testimony.

"Veio-me, repentinamente, um horror à sociedade e à vida; uma vontade de absoluto
aniquilamento, mais do que aquele que a morte traz; um desejo de perecimento total
da minha memória na terra; um desespero por ter sonhado e terem me acenado tanta
grandeza, e ver agora, de uma hora para outra, sem ter perdido de fato a minha
situação, cair tão, tão baixo, que quase me pus a chorar que nem uma criança."
(Lima Barreto, O cemitério dos vivos - fragmentos - cap. II)

Embora a literatura brasileira já conte com um alto número de memórias e escritos autobiográficos, são raras as obras que possam valer como testemunhos diretos e coerentes de um estado de opressão e humilhação. Esse é o caso do "Diário do hospício" de Lima Barreto.

O que me impressiona quando leio $O$ cemitério dos vivos é o efeito de serena lucidez que sai dessas páginas escritas em um asilo de alienados. Lima Barreto, internado no casarão da Praia Vermelha no dia de Natal de 1919, mostra-se consciente dos motivos que o arrastaram àquela situação de extrema abjeção social: "De mim para mim, tenho certeza que não sou louco; mas devido ao álcool, misturado com toda a espécie de apreensões que as 
dificuldades de minha vida material há seis anos me assoberbam, de quando em quando dou sinais de loucura: deliro". ${ }^{1}$

As primeiras anotações do "Diário do hospício" datam de 4 de janeiro de 1920, quinze dias depois de sua entrada no manicômio. A linguagem é transparente, o andamento da prosa é moderado, aparentemente sem surpresas, o que não prejudica a densidade de observação e pensamento crítico que pulsa em cada frase.

Observação, em primeiro plano. O "alienado" olha com atenção analítica o espaço onde o querem encerrar a polícia e o aparelho psiquiátrico da República Velha na capital da belle époque: "Não me incomodo muito com o hospício, mas o que me aborrece é essa intromissão da polícia em minha vida".

Desde o início dos seus apontamentos Lima Barreto mostra que a polícia é um instrumento que serve de veículo para encaminhar o suposto demente a um lugar apartado, na medida em que ele é confundido com o marginal. Por algum tipo de comportamento considerado anormal, deve ser retirado da sociedade e encerrado em uma espécie de depósito onde os seres "normais" não o vejam nem mantenham com ele qualquer contacto. O aparelho policial aparece, mais de uma vez, como a primeira triagem, que separa o joio do trigo social. O joio será em seguida peneirado: de um lado, o meliante, que vai para a delegacia e a cadeia; de outro, essa figura estranha, paradoxal, quase inclassificável, o réu sem culpa, mas igualmente forçado à reclusão.

Se na cela do presídio o réu era seviciado antes de qualquer sentença do juiz, o que Lima sofreu nas dependências do casarão da Praia Vermelha foi uma série de violências que ainda se praticavam na maioria dos hospícios da República Velha. Convém lembrar que esse tipo de tratamento não era uma singularidade brasileira, pois reproduzia práticas correntes em manicômios europeus do século XIX.

A primeira violência se fez ao seu pudor: "Todos nós estávamos nus, de portas abertas, e eu tive muito pudor".

A consciência desse homem obrigado à nudez pública é atravessada pela memória do leitor de romance, nada menos que outra obra de pungente testemunho de humilhação, as Recordações da Casa dos Mortos: "Eu me lembrei do banho de vapor de Dostoievski, na Casa dos Mortos. Quando baldeei, chorei; mas lembrei de Cervantes, do próprio Dostoievski, que pior deviam ter sofrido em Argel e na Sibéria. Ah! A Literatura, ou me mata ou me dá o que eu peço dela".

Faz sentido registrar essa capacidade do intelectual que consegue relativizar o seu vexame comparando-o com afrontas suportadas por seus ídolos distantes, mas feitos próximos pela ação mediadora da memória. É por força dessa mesma disposição de pensar que o escritor Lima Barreto, jogado no meio de loucos indigentes, ora nu ora coberto de trapos, encara sem sombra de sujeição o médico do hospício, o homem a quem a sociedade atribuíra o direito de decidir da sua reclusão naquele depósito de seres... anormais.

Raul Pompéia desmistificara no Ateneu a propaganda pedagógica do colégio mais afamado e moderno do Império: o seu romance fez contra-ideologia solitária em um campo arado pelas certezas do progresso do século investidas na educação. Cruz e Sousa, curvado sob o peso de preconceitos de cor, lançara um repto à pseudociência racista hegemônica no seu tempo. Lima Barreto, que pertence à geração pós-abolicionista da Primeira República, enfrenta com o mesmo desassombro e a mesma solidão a rotina carcerária solidamente apoiada em velhos modelos europeus que resistiam às mudanças das novas teorias psiquiátricas.

Analisando com frio distanciamento as pretensões científicas de um alienista do hospício, Henrique Roxo, diz o nosso memorialista:

\footnotetext{
${ }^{1}$ As citações foram extraídas de Lima Barreto, O cemitério dos vivos, Prefácio de Eugênio Gomes, São Paulo, Brasiliense, 1956.
} 
Ele me parece desses médicos brasileiros imbuídos de um certo ar de certeza, desdenhando inteiramente toda outra atividade intelectual que não a sua e pouco capaz de examinar o fato por si. Acho-o muito livresco e pouco interessado em descobrir, em levantar um pouco o véu do mistério - que mistério! - que há na especialidade que professa. Lê os livros da Europa, dos Estados Unidos, talvez; mas não lê a natureza. ${ }^{2}$

O texto fala por si na sua ácida clareza. Ao lado da arrogância clínica, marca registrada da auto-suficiência de boa parte dos psiquiatras do século XX, Lima aponta o desinteresse em face do drama individual, do fato em si ou, com palavra mais abrangente, da natureza. O doutor Roxo não chega perto do corpo e da alma do homem que sofre e que está diante dele; como alienista, só tem duas certezas, o manual que leu no curso médico e o manicômio no qual deposita todas as presunções da sua terapia.

Mas é de maneira indireta que Lima dirá o seu pensamento, atribuindo ao irmão as convicções que entrevê no alienista: "Depois, disse-lhe que tinha sido posto ali por meu irmão, que tinha fé na onipotência da ciência e a crendice do hospício. Creio que ele não gostou".

Nem tudo é crítica acerba. O observador social percebe certo clima de camaradagem e tolerância que aproxima os enfermeiros, "homens rústicos mal saídos da gleba do Minho e os brasileiros, da mais humilde extração urbana", que tratam com resignação e delicadeza os doentes e suas manias. Abre-se ao leitor de hoje um quadro de sociabilidade popular, no qual talvez o profissionalismo ainda não congelara as relações cotidianas mesmo dentro de uma instituição regida por uma ciência que se desejava asceticamente impessoal.

Voltando a analisar um dos alienistas, reponta a veia satírica:

Não lhe tenho nenhuma antipatia, mas julgo-o mais nevrosado e avoado do que eu. É capaz de ler qualquer novidade de cirurgia aplicada à psiquiatria em uma revista norueguesa e aplicar, sem nenhuma reflexão preliminar, num doente qualquer. É muito amante de novidades, do vient de paraître, das últimas citações científicas ou que outro nome tenham.

Nesse contexto de interações entre o paciente e o psiquiatra, em que prevalece o distanciamento crítico, chama a atenção um momento de excepcional simpatia. O encontro do internado com o diretor do hospício, Juliano Moreira, alienista de grande prestígio no primeiro quartel do século XX, dá-se em um clima de cordialidade que suscita no memorialista ressonâncias afetivas intensas. No "Diário do hospício", série de apontamentos que abre o livro, Lima Barreto anotou:

Na segunda-feira, antes que meu irmão viesse, fui à presença do doutor Juliano Moreira. Tratou-me com grande ternura, paternalmente, não me admoestou, fez-me sentar a seu lado e perguntou-me onde queria ficar. Disse-lhe que na Seção Calmeil. Deu ordens ao Sant'Ana e, em breve, lá estava eu.

\footnotetext{
${ }^{2}$ Em uma crônica escrita para a Careta, em 30 de outubro de 1915, quatro anos antes da internação que deu origem a esse "Diário do hospício", Lima Barreto já fazia a sátira dos alienistas rotuladores dos chamados doentes mentais. Em "As teorias do doutor Caruru", o cronista fala de um subdiretor do Manicômio Nacional, autor de Os caracteres somáticos da degenerescência, que repetia teorias de Lavater e de Gall. Sintomaticamente, o doutor Caruru se vê às voltas com um "exemplar típico de dipsomaníaco de degenerado superior": trata-se de um jovem pintor que estreara brilhantemente, mas cuja carreira tinha sido interrompida pela "mais desordenada boêmia". A crônica tem um quê indisfarçável de autobiogáfico, tendo sido escrita pouco depois da primeira internação de Lima no Hospício Nacional, entre agosto e outubro de 1914. Ao mesmo tempo, inscreve-se na sátira aos doutores brasileiros e às suas pretensões de onisciência. Ver Lima Barreto, Toda crônica, org. de Beatriz Resende e Rachel Valença, Rio de Janeiro, Agir, 2004, v. I, p. 248-50.
} 
Em $O$ cemitério dos vivos, o narrador, travestido em personagem, aprofunda o sentimento que aquele encontro lhe tinha inspirado:

Conhecia perfeitamente o diretor e travei conhecimento com ele espontaneamente. Havia em mim uma cega atração para ele e eu me espantava que ele pudesse, sem barulho, mansamente, se fazer até onde estava. Pouco conhecia de sua vida... Todos gabavam muito o seu talento, a sua ilustração; mas não era bem por isso que eu o amava. Nunca lhe tinha lido um trabalho, só mais tarde me foi dado fazer isso, não tinha nenhuma ilustração no assunto do seu saber para julgar; mas, conquanto sentisse logo um homem superior, eu o amava pela sua exalação de doçura.

Trata-se, literalmente, de um episódio, isto é, de um evento sem precedentes nem continuidade ao longo da obra. Creio que nele se possam discernir ao menos dois significados. O primeiro, que é patente, e cresce de um texto para o outro, diz respeito ao envolvimento afetivo que a benevolência paternal do alienista desencadeou no pobre e fragilizado Lima conduzido, à sua revelia, à casa dos loucos da Praia Vermelha. Diante do médico famoso, mas despido de vaidade, delicado e terno, o recém-internado responde com um sentimento misto de admiração e amor. O segundo significado pode ser inferido pelo contraste, e tem uma dimensão social ou, mais precisamente, institucional que vale a pena destacar: o talento e a doçura do diretor do hospício (que, em entrevista a um jornal carioca, Lima chamaria de "domínios do sr. Juliano Moreira") não conseguiam alterar algumas práticas vexatórias daquele manicômio, dando a entender que os mecanismos das instituições se reproduzem e resistem pela força da inércia às eventuais qualidades de inteligência e coração dos seus dirigentes. Daí o valor dos testemunhos (diretos ou ficcionais) pelos quais a literatura de cunho autobiográfico alcança matizar a história das instituições e de suas ideologias, cujo risco é subestimar o drama das experiências individuais. ${ }^{3}$

Lançado em meio a seres humanos que deliram, Lima Barreto é sempre o escritor de cepa realista que se propõe a "pegar agora no lápis para explicar bem estas notas que vou escrevendo no hospício". As marcas de tempo são precisas: agora e vou escrevendo remetem ao presente imediato e fazem supor que não tenha corrido intervalo entre a situação objetiva e o ato de transcrevê-la. No entanto, essa imediação é relativa. A simultaneidade das vozes dos dementes com o empenho de redigir o diário não impede o lúcido analista de cavar, na hora mesma da escrita, outro tempo, o da memória do leitor que um dia se impressionou com as

\footnotetext{
${ }^{3}$ Os estudos sobre a psiquiatria brasileira e as instituições manicomiais do começo do século XX confirmam a impressão favorável que Juliano Moreira despertou em Lima Barreto. Trata-se de uma figura rara de intelectual que, mulato e de origem modesta, batalhou para conquistar o seu lugar como alienista reconhecido por seus pares. Não compartilhou dos preconceitos arianizantes do seu tempo, discordando das posições de Nina Rodrigues no tocante às supostas inconveniências da mestiçagem na formação do povo brasileiro. Seu papel progressista é assim sintetizado por Vera Portocarrero em Arquivos da loucura. Juliano Moreira e a descontinuidade histórica da psiquiatria, Rio de Janeiro, Fiocruz, 2002, p. 13-14: "Juliano Moreira representa o primeiro esforço de elaboração de um corpo teórico científico no Brasil, ao rejeitar a simples compilação das teorias psiquiátricas francesas. Ele introduziu, no início do século 20, o modelo teórico e assistencial baseado na psiquiatria alemã, representado pelo eminente psiquiatra Emil Kraepelin. Juliano Moreira ocupou, de 1903 a 1930, o cargo de diretor geral da Assistência a Psicopatas do Distrito Federal. Conseguiu a promulgação de uma lei de reforma da assistência a alienados. Remodelou o antigo Hospício de Pedro (retirada de grades, abolição dos coletes e das camisas de força), onde instalou um laboratório. Criou, em 1911, a Colônia de Engenho de Dentro. Instaurou a admissão voluntária de insanos e assistência heterofamiliar. Em 1919, inaugurou o primeiro Manicômio Judiciário do Brasil”. Juliano Moreira teria, igualmente, dado importância secundária aos componentes hereditários (e, no limite, raciais) da loucura, considerando, ao contrário, como fatores de risco mais ativos o hábito da embriaguez e os efeitos neurológicos da sífilis e das moléstias degenerativas. No seu diário, Lima aceita o diagnóstico que apontava o alcoolismo como causa principal dos seus delírios, mas o relativiza ao dar peso às condições sociais e psicológicas do seu cotidiano. Quanto à ação humanizadora promovida por Juliano Moreira na vida interna do hospício, pode-se inferir, pelo testemunho de Lima Barreto, que nem sempre a sua teoria e as suas boas intenções logravam o efeito desejado.
} 
páginas de um livro célebre, $O$ crime e a loucura, de Maudsley, nome que também ocorrera a Euclides da Cunha no fecho trágico de Os sertões.

A obra de Maudsley, manual conceituado de psiquiatria positiva e moralizante do fim do século XIX, emitia conselhos para evitar a loucura: em primeiro lugar, o mandamento de não beber alcoólicos. "Nunca o cumpri”, diz Lima, "e fiz mal". A narrativa volta a fazer-se autobiográfica, como se o livro rememorado servisse de ponte entre as notas que falavam da loucura alheia e as palavras de auto-análise de um eu que não só vê e escreve, mas lê, recorda e se julga a si mesmo. Que trama de operações intelectuais sob a aparência do mais despretensioso dos diários!

O título da passagem "A minha bebedeira e a minha loucura" não poderia ser mais transparente. $\mathrm{O}$ álcool aí aparece como causa próxima dos delírios que levaram o escritor ao manicômio. A anamnese vai mais longe e toca mais fundo, buscando sondar os motivos do vício, que Lima acaba reduzindo a um só estado crônico de angústia neste passo de notável densidade existencial:

Muitas causas influíram para que viesse a beber; mas, de todas elas, foi um sentimento ou pressentimento, um medo, sem razão nem explicação, de uma catástrofe doméstica sempre presente. Adivinhava a morte de meu pai e eu sem dinheiro para enterrá-lo; previa moléstias com tratamento caro e eu sem recursos; amedrontava-me com uma demissão e eu sem fortes conhecimentos que me arranjassem colocação condigna com a minha instrução; e eu me aborrecia e precisava distrair-me, ficava na cidade, avançava pela noite adentro, e assim conheci o chopp, o whisky, as noitadas, amanhecendo na casa deste ou daquele.

Nossa memória vai às Recordações do escrivão Isaías Caminha e aos vexames do mocinho inteligente e brioso batendo de porta em porta à procura de empregos humildes, mas recusados porque ele trazia na pele o estigma da mestiçagem ainda tão vivo naquela República recente e velha. Não por acaso, as anotações que se seguem à auto-análise trazem referências àquele romance, publicado em tempos de entrega à bebida misturada com o desejo insofrido de luta, de polêmica, que se frustrou: "O aparecimento do meu primeiro livro não me deu grande satisfação. Esperava que o atacassem, que me descompusessem e eu, por isso, tendo o dever de revidar, cobraria novas forças, mas tal não se deu; calaram-se uns e os que dele trataram o elogiaram. É inútil dizer que nada pedi”.

Por sua vez, a tiragem em folhetos do Triste fim de Policarpo Quaresma pelo Jornal do Comércio foi recebida por um silêncio confrangedor ("Ninguém o leu"), só compensado, anos depois, pela recepção do livro. Quanto à Vida e morte de M. J. Gonzaga de Sá, também era um pesadelo para Lima, pois "eu tinha a íntima certeza de que não encontraria dinheiro com que me fosse possível editar o meu trabalho, especialmente o Gonzaga de Sá". Sem o exame dos sentimentos e ressentimentos do escritor frustrado como poderiam os psiquiatras de plantão entender os motivos que levavam o suposto alienado a embriagar-se até chegar às raias do delírio?

Conhecendo as simpatias de Lima Barreto pelos ideais revolucionários que irradiaram da Europa para o Brasil no começo do século XX, o comunismo, na sua versão maximalista, e o anarquismo, tem-se curiosidade de saber se teriam entrado, de algum modo, nos delírios persecutórios que motivaram a sua internação. Há testemunhos indiretos de que Lima foi tomado de pavor ao imaginar-se perseguido por um militar ligado ao marechal Hermes da Fonseca, o tenente Serra Pulquério.

Consta dos registros médicos do Hospício Nacional dos Alienados datados de 27 de agosto de 1914, relativos à sua primeira internação:

Interrogado sobre o motivo da sua internação, refere que, indo à casa de um seu tio em Guaratiba, prepararam-lhe uma assombração, com aparecimento de fantasmas, que 
aliás lhe causam muito pavor; nessa ocasião, chegou o Tenente Serra Pulquério, que, embora seu amigo de "pândegas", invectivou-o por saber que preparava panfletos contra seus trabalhos na Vila Proletária Marechal Hermes. Tendo ele negado, foi conduzido à polícia, tendo antes cometido desatinos em casa, quebrando vidraças, virando cadeiras e mesas. A sua condução para a polícia só se fez mediante o convite do comissário que the deu aposento na delegacia até que transferiram-no para a nossa clínica. Protesta contra o seu "sequiestro", pois vai de encontro à lei, uma vez que nada fez que o justifique. Nota de certo tempo para cá animosidade contra si, entre os seus companheiros de trabalho, assim como entre os próprios oficiais do Ministério da Justiça, de onde é funcionário. Julga que o Tenente Serra Pulquério teme a sua fama, "ferina e virulenta", pois, apesar de não ser grande escritor, nem ótimo pensador, adota as doutrinas anarquistas e quando escreve deixa transparecer debaixo de linguagem enérgica e virulenta os seus ideais.

O "Diário", porém, é parco em declarações explicitamente ideológicas. A rigor, uma citação de Plutarco, cujas Vidas paralelas foram leitura assídua do internado: "As leis são como as teias de aranha que prendem os fracos e pequenos insetos, mas são rompidas pelos grandes e fortes". Lima acrescenta: "Palavras de um sábio cita Anacársis, citado por Plutarco, na vida de Sólon”. É na relação íntima entre os gestos e palavras dos alienados e as violências e arbítrios da sociedade abrangente que deve ser extraída a matéria da contra-ideologia rebelde de Lima Barreto.

Nesse ir e vir entre o sujeito e o seu mundo que é o "Diário do hospício", sempre que o narrador sai de si mesmo o tom é de perplexidade cognitiva. A interrogação que abre o capítulo "Alguns doentes" exprime o movimento de um espírito que deseja mas não consegue compreender aqueles homens cuja convivência lhe fora imposta: "Que dizer da loucura?".

A pergunta vem de um espírito agudo que não acredita que haja uma resposta única, científica, para a questão. Ao contrário, recolhido ao hospício, a sua reflexão tendia a negar os postulados e os quadros classificatórios da psiquiatria determinista. O que resultava em um passo nada desprezível na história da compreensão dos internados, descritos por ele como pessoas diferenciadas, e não simples exemplos capazes de ilustrar esquemas já previstos nos tratados de patologia mental. Se confrontamos as doutrinas que vigoravam em todo o Ocidente nesse começo do século XX com a percepção individualizante de Lima Barreto, não deixaremos de admirar o seu precoce discernimento:

Que dizer da loucura? Mergulhado no meio de quase duas dezenas de loucos, não se tem absolutamente uma impressão geral dela. Há, como em todas as manifestações da natureza, indivíduos, casos individuais, mas não há ou não se percebe entre eles uma relação de parentesco muito forte. Não há espécies, não há raças de loucos; há loucos só.

Quem diz essas palavras certamente não partilharia das certezas da psicofisiologia de um Ribot, cujas obras prestigiosas figuram na biblioteca de Lima, nem das classificações de Franco da Rocha, citado entre as últimas anotações do Diário íntimo (dezembro de 1921). De passagem, lembro que um leitor do Policarpo Quaresma, o dr. Luís Ribeiro do Vale, escreveu, em 1917, uma tese de doutoramento cujo título era A psicologia mórbida na obra de Machado de Assis...

O pensamento continua, linhas adiante: "Há uma nomenclatura, uma terminologia, segundo este, segundo aquele; há descrições pacientes de tais casos, revelando pacientes observações, mas uma explicação da loucura não há". E, relativizando os procedimentos clínicos que acreditavam cercar a etiologia da demência acusando fatores hereditários, faz este comentário perspicaz: "Procuram os antecedentes do indivíduo, mas nós temos milhões deles 
e, se nos fosse possível conhecê-los todos, ou melhor, ter memória dos seus vícios e hábitos, é bem certo que, nessa população que cada um de nós resume, havia de haver loucos, viciosos, degenerados de toda a sorte".

É provável que, sofrendo em carne e osso a experiência de passar por insano, mas bem consciente de que não o era ("De mim para mim, tenho certeza que não sou louco"), o intelectual Lima Barreto estivesse alcançando uma percepção nítida do caráter toscamente discriminatório de certa psiquiatria determinista do século XIX, cujas explicações, como ele mesmo aponta, resumiam-se a nomenclaturas e terminologias, isto é, a classes e palavras. Daí vem o mordente da sua crítica às instituições manicomiais que, na sua lógica perversa, pareciam compensar, pela sinistra igualdade de uma espécie de morte em vida (que é o seqüestro), as diferenças de classe que os jazigos e as covas rasas perpetuam nos cemitérios...

Amaciado um pouco, tirando dele a brutalidade do acorrentamento, das surras, a superstição das rezas, exorcismos, bruxarias, etc., o nosso sistema de tratamento ainda é o da Idade Média: o seqüestro. Não há dinheiro que evite a Morte, quando ela tenha de vir; e não há dinheiro nem poder que arranque ao homem da loucura. Aqui, no hospício, com as suas divisões de classe, de vestuário, etc., eu só vejo um cemitério: uns estão de carneiro e outros de cova rasa.

Quanto às hipóteses que se arquitetavam a respeito da origem da sua loucura, atribuindo-a tão-só à bebida, parecem-lhe reducionistas e, quando generalizadas, "absolutamente pueris". A auto-análise leva-o a sondar outras matrizes para compreender os desequilíbrios da mente e do comportamento. Lima atenta para os percursos surpreendentes da libido (teria lido Freud?): "acode-me refletir por que razão os médicos não encontram no amor, desde o mais baixo, o mais carnal, até a sua forma mais elevada, desdobrando-se num verdadeiro misticismo, uma divinização do objeto amado; por que - pergunto eu - não é fator de loucura também?".

E adiante, revelando intuição dos condicionamentos sociais, refere-se ao dinheiro e ao desejo de status como desencadeadores da insanidade: "Por que a riqueza, base de nossa atividade, coisa que, desde menino, nos dizem ser objeto da vida, da nossa atividade na terra, não é também causa da loucura? Por que as posições, os títulos, cousas também que o ensino quase tem por meritório obter, não é causa de loucura?"

Como em tantas outras passagens, porém, o alvo da pergunta sobre as razões da desrazão só é atingido de modo convincente quando o narrador fala de si mesmo, da sua carreira literária malograda por vários motivos, alguns involuntários, devidos à má sorte e à estreiteza do meio onde lhe foi dado viver. Nesses momentos de introspecção $O$ cemitério dos vivos traz ecos das recordações de Isaías Caminha, que a crítica elogiosa mas severa de José Veríssimo censurara por ser "personalíssimo", ou seja, excessivamente autobiográfico:

Desde a minha entrada na Escola Politécnica [em 1897, com 17 anos de idade] que venho caindo de sonho em sonho e, agora que estou com quase quarenta anos, embora a glória me tenha dado beijos furtivos, eu sinto que a vida não tem mais sabor para mim [...]. Esta passagem várias vezes no hospício e outros hospitais deu-me não sei que dolorosa angústia de viver que eu me parece ser sem remédio a minha dor. Vejo a vida torva e sem saída. [...] Ainda tenho alguma verve para a tarefa do dia a dia, mas tudo me leva para pensamentos mais profundos, mais doridos e uma vontade de penetrar no mistério da minha alma e do Universo.

Da mesma matriz do malogro brotam o delírio e a pausada meditação existencial.

\section{O elo entre o testemunho e a ficção}


O leitor se surpreenderá ao constatar que, no exato momento em que o depoente entra a escavar o passado e aprofundar a sua "angústia de viver", o texto confessional cede a um lance de ficção. O testemunho que, até então, parecia pura transcrição dos apontamentos de um internado, converte-se na matéria romanesca de uma novela inacabada, cujo título será igualmente $O$ cemitério dos vivos. Veja-se de perto a passagem em que se opera a mudança de registro.

Perguntando a si mesmo se, por acaso, não teria sido o amor o fator erosivo da sua existência malograda, o narrador, agora ficcional, responde pela negativa em tom drástico:

Não amei nunca, nem mesmo minha mulher que é morta e pela qual não tenho amor, mas remorso de não tê-la compreendido mais devido à oclusão muda do meu orgulho intelectual; e tê-la-ia amado certamente, se tão estúpido sentimento não tivesse feito passar por mim a única alma e pessoa que me podiam inspirar tão grave pensamento. Li-a e não a compreendi... Ah! meu Deus!

A biografia de Lima Barreto, que se conhece em detalhe graças a pesquisas meticulosas (de que a obra de Francisco de Assis Barbosa é exemplo notável), desmente de maneira cabal a existência de uma esposa ou companheira desse homem solitário, talvez misógino, "limitando-se os seus contactos com as mulheres ao convívio com a irmã, também solteira, e aos encontros ocasionais com meretrizes. ${ }^{4}$

Podem-se ler, no entanto, frases soltas em pleno "Diário do hospício", que prenunciam aquela passagem do depoimento para o discurso ficcional.

Há um indício isolado no capítulo 5 do "Diário". Alguém irrompe no aposento de Lima e pergunta: “Quem é aí Tito Flamínio?". Lima, autor do diário, responde imediatamente: “'Sou eu', apressei-me”. É aparentemente inexplicável essa mudança de nome em um contexto francamente autobiográfico.

No capítulo 7, aparecia de repente uma figura de "mulher" (no contexto, esposa) já morta: "Falta-me amor ou ter amado. Mas... Minha mulher! Não posso tratar dela. Não se ama uma morta, e eu não a soube amar em vida".

A figura, depois evocada no romance como "minha mulher que é morta", significa o salto para o plano do imaginário dado em um texto que respira, do começo ao fim, a idoneidade da testemunha ocular. Ao mesmo tempo, é essa aparição-fantasma, que a psicanálise poderia interpretar em termos de Thanatos sobrepondo-se a Eros, que abre $O$ cemitério dos vivos (fragmentos) posterior às anotações do hospício: "Quando minha mulher morreu, as últimas palavras que dela ouvi, foram estas, ditas em voz cava e sumida: Vicente, você deve desenvolver aquela história da rapariga, num livro".

A matéria-prima do diário será trabalhada pelo regime da invenção romanesca. Uma esposa à beira da morte, a sombra de um filho de quatro anos que passa quase despercebida, e um casamento consumado sem paixão. Mas o interesse maior, se não exclusivo, do enredo está na história da formação intelectual rebelde e autodidática de Vicente, com toda a sua aversão ao culto bacharelesco, ao status dos doutores "brancos" e à prática do "pistolão", que vigorava naquela sociedade entre burguesa e tradicional do Rio de Janeiro em plena belle époque.

A novela ficou inacabada. Foi pena, pois a substância autobiográfica (evidente nos episódios transpostos das páginas do diário) começava a resolver-se em uma prosa enxuta e

\footnotetext{
${ }^{4}$ Francisco de Assis Barbosa, "Lima Barreto, precursor do romance moderno", in Lima Barreto, prosa seleta, Rio de Janeiro, Nova Aguilar, 2001, p. 96; A vida de Lima Barreto (1881-1922), obra fundamental do mesmo autor, saiu em 1952. Recomendo a 8 a edição, publicada pela Ed. José Olympio, com notas de revisão de Beatriz Resende (Rio de Janeiro, 2002).
} 
pensada, só comparável às boas passagens dos romances levados a termo. De todo modo, impressiona a figura da mulher que morre na primeira frase do livro. E ainda mais intriga a sua última palavra ao marido, a quem pede que escreva um texto de ficção, que ele apenas esboçara.

O narrador, fixando o olhar da mulher agonizante, diz que a dor nele estampada "não era bem de mulher, mas de mãe amantíssima". Segue-se a história do casamento, que ele próprio chama de singular: uma união provocada pela necessidade premente de apoio de uma jovem desvalida, que toma a iniciativa de oferecer-se como esposa a Vicente. Ela o ama deveras, mas ele apenas lhe dedicaria sentimentos muito pouco eróticos de estima e compaixão. O desencontro é pungente, mas o fato de não ter sido explorado a fundo leva a suspeitar que a relação homem-mulher foi encoberta (subestimada? recalcada?) pelo narrador, ao passo que subia ao primeiro plano a amargura do intelectual humilhado na cor e na classe, aqui agravada pelo vexame do encarceramento no hospício.

As menções a Efigênia têm muito de piedade ("Nunca mais se foi de mim a imagem daquela pobre moça a morrer com pouco mais de vinte e cinco anos") e de arrependimento por não ter reconhecido a tempo a sua agudeza intelectual e a solicitude com que ela se preocupava com a sua realização como escritor.

Aquele último pedido ("Vicente, você deve desenvolver aquela história da rapariga, num livro"), aparentemente estranho, não fora, na verdade, uma nota isolada. A moça pontuara com matérias de literatura o seu casto assédio a Vicente: eram livros de empréstimo, eram comentários de leituras, eram convites à ficção e à poesia aos quais o mocinho arredio e meio abstrato dera pouca importância. A figura de Efigênia, que o narrador mostra apagada quando viva, ressurgirá como "excepcional" na linguagem do remorso impotente do viúvo. A rigor, o diálogo com a mulher não chegara a tomar corpo: se viera de Efigênia o apelo à criação literária, com a nota pungente do último conselho, do lado de Vicente só se conhece a confessada "oclusão muda do meu orgulho intelectual".

Resta ao leitor a tarefa de desfazer o nó existencial armado por essa combinação de testemunho e ficção. O entreato conjugal de Vicente e Efigênia só é vivido, ou melhor, representado, no regime dos fragmentos romanescos de $O$ cemitério dos vivos. A mulher que ama, em princípio desvalida, depois maternal, percebe claramente que o amado só tem uma paixão constante, ser escritor e intelectual respeitado, mas que a sua compleição moral frágil, vulnerável, o impede de superar-se e realizar a obra que o arrancaria do anonimato. O marido, amado, mas não apaixonado, fecha-se na impotência do seu amor próprio, que a expressão "oclusão muda do meu orgulho intelectual" enuncia com precisão. A morte da mulher o punge como um remorso incontornável. Parece que Lima Barreto precisava transpor para a esfera do imaginário, no caso, pela invenção de um episódio conjugal frustrante, o seu drama fundamental de saber-se ao mesmo tempo capaz de uma alta produção literária e oprimido por um conjunto de condições sociais adversas.

O livro sustenta-se às vezes sob a forma de longa ruminação sobre o significado mesmo da existência quando tudo ao redor do sujeito carece precisamente de sentido. Lembro, a propósito, o quanto rendeu em termos de reflexão um episódio curto mas crucial. Um rapazinho pergunta a Vicente se este fora parar no hospício por ter cometido algum crime. Ouvindo a resposta pronta e veemente de que fora apenas uma bebedeira a causa da internação, o pequeno delinqüiente conta com a maior naturalidade que lá estava precisamente por um crime. Essa naturalidade - cândida? isenta de cinismo? - do jovem internado, quase um menino, desencadeia no narrador um estado de angústia insuportável: mal estar que nasce de uma intuição do absurdo de todas as doutrinas éticas ou racionais que procuram magnificar a ordem do universo e o valor da pessoa humana.

Vicente, assim como o Lima Barreto dos depoimentos, diz que freqüentara as sessões do Apostolado Positivista onde ouvira as prédicas austeras mas sistematicamente otimistas do 
senhor Teixeira Mendes, como chama o sacerdote nacional da religião da Humanidade. Nos sermões de inspiração comteana repetiam-se as palavras do mestre confiantes no porvir do Grande-Ser:

O amor por princípio, a ordem por base e o progresso por fim; tal é o caráter fundamental do regime definitivo que o positivismo vem inaugurar sistematizando toda a nossa existência, moral e social, por uma combinação inalterável entre o sentimento, a razão e a atividade [...]. A supremacia necessária da vida afetiva aí se encontra melhor constituída do que antes, conforme a preponderância universal do sentimento social, que pode diretamente encantar todo e qualquer pensamento e ato. ${ }^{5}$

Compare-se a linguagem coesa e assertiva de Comte com o relativo à-vontade da dicção de Lima Barreto e até mesmo o desleixo estilístico da sua redação, traços que não devem impedir o reconhecimento da sua capacidade de passar do caso singular à meditação universalizante, e vice-versa. É prosa de escritor sofrido, carregado de memórias amargas e, ao mesmo tempo, densamente reflexivo:

O curto encontro com esse rapazola criminoso, ali, naquele pátio, mergulhado entre malucos a delirar, a fazer esgares uns; outros, semimortos, aniquilados, anulados, encheram-me [sic] de um grande pavor pela vida e de um sentimento profundo da nossa incapacidade para compreender a vida e o universo. Lembrei-me, então, dos outros tempos, em que supus o universo guiado por leis certas e determinadas, em que nenhuma vontade, humana ou não, a elas estranha, poderia intervir, leis que a ciência humana iria aos poucos desvendando... Não sorri inteiramente, mas achei tal coisa ingênua e que todo o saber humano só seria útil para as suas necessidades elementares da vida e nunca conseguiria explicar a sua origem e o seu destino.

Pensamentos induzidos pelo "grosso espetáculo doloroso da loucura", e que se somam a outros momentos especulativos a que as leituras de Lima Barreto deram fecundo humus cultural.

\section{O projeto e o texto}

Nos últimos dias da sua estada no Hospício Nacional de Alienados, Lima Barreto deu uma entrevista ao jornal carioca $A$ Folha, que saiu na edição de 31 de janeiro de 1920.

Louvado então como "o romancista admirável de Isaías Caminha", posto que "boêmio incorrigível", ele revela ao jornalista os seus "planos de trabalho". Mostra-se, em suas palavras, satisfeito e pronto a voltar ao mundo. E diz ironicamente que, apesar das restrições à liberdade ("o Hospício é uma prisão como outra qualquer"), a sua internação estava sendo útil, pois lhe permitia coligir "observações interessantíssimas para escrever um livro sobre a vida interna dos hospitais de loucos". Não deixa de exortar o jornalista a ler $O$ cemitério dos vivos, quando saísse em livro. Referia-se provavelmente ao diário e não à novela que receberia o mesmo título. No final da entrevista, recusa um pedido de adiantar ao jornal suas notas sobre os "tipos interessantes" que começara a descrever, pois, feita a revelação, o livro "perderia todo o interesse". "E Lima Barreto, sorrindo, arrancou do bolso um pedaço de papel: - Estás vendo? São uns tipos que acabo de jogar".

Há casos em que o texto acabado resulta inferior ao projeto inicial.

Aqui, deu-se o contrário: o texto inacabado superou os planos concebidos nos dias da internação. O narrador fez mais que alinhar "tipos interessantes”. Esses comparecem, de fato,

\footnotetext{
${ }^{5}$ Auguste Comte, Discours sur l'ensemble du positivisme (1848), Paris, Flammarion, 1998, p. 345.
} 
mas descritos de modo sumário, esboços de indivíduos que não lograriam subir à categoria de personagens quando transpostos para o corpo da novela. $\mathrm{O}$ escritor não quis ou não pôde desenvolvê-los, justamente porque foi o enigma da loucura, em si, que o atraiu desde os primeiros contactos feitos no pavilhão dos indigentes. Nos loucos o mutismo ou os gritos, os esgares ou as explosões de violência, o sombrio retraimento ou a familiaridade viscosa - tudo lhe parecia inexplicável, e não é à toa que o observador precisasse recorrer, mais de uma vez, à palavra mistério.

Perplexo, o intelectual crítico, cuja obra toda fora uma denúncia da mentira social, teme que os médicos do hospício o tratem de maneira cega ou arbitrária. Teme principalmente que a ciência livresca que seguem, avessa à idéia mesma de enigma, não lhes permita ter dúvidas, nem lhes faça ver pessoas, mas apenas casos exemplares devidamente catalogados e passíveis das terapias reificadas nos manuais de psiquiatria.

A impotência do internado, que já sofrera o arbítrio dos policiais com seus preconceitos de cor e classe, vê-se, de repente, confrontada com a onipotência do médico. A assimetria é brutal, e, embora Lima tenha escapado ao risco de virar cobaia de alienistas enrijecidos ou precipitados, a sua crítica guarda um potencial de verdade ainda hoje ameaçador:

O terrível nessa coisa de hospital é ter-se de receber um médico que nos é imposto e muitas vezes não é da nossa confiança. Além disso, o médico que tem em sua frente um doente, de que a polícia é tutor e a impersonalidade da lei, curador, por melhor que seja, não o tem mais em conta de gente, é um náufrago, um rebotalho da sociedade, a sua infelicidade e desgraça podem ainda ser úteis à salvação dos outros, e a sua teima em não querer prestar esse serviço aparece aos olhos do facultativo como a revolta de um detento, em nome da Constituição, aos olhos de um delegado de polícia.

Em relação aos jovens recém-formados, amantes de novidades e pouco dispostos a analisar detidamente seus pacientes, confessa que a sua própria condição "de desgraçado" dava-lhe o temor de que o médico "quisesse experimentar em mim um novo modo de curar alcoolismo em que empregasse uma operação melindrosa e perigosa. Pela primeira vez, fundamentalmente, eu senti a desgraça e o desgraçado. Tinha perdido toda a proteção social, todo o direito sobre o meu próprio corpo, era assim como um cadáver de anfiteatro de anatomia".

O desrespeito ao que se poderia chamar hoje de direitos mínimos do cidadão assoma de modo flagrante na fase policial que precede a entrada no hospício. Sempre subsiste alguma coisa de tristemente comum entre o guarda de rua e o guarda do manicômio; a ação violenta de ambos procura apagar o indivíduo e substituí-lo pelo estereótipo:

A polícia, não sei como e por que, adquiriu a mania das generalizações, e as mais infantis. Suspeita de todo sujeito estrangeiro com nome arrevesado, assim os russos, polacos, romaicos são para ela forçosamente caftens; todo cidadão de cor há de ser por força um malandro; e todos os loucos hão de ser por força furiosos e só transportados em carros blindados.

Leia-se, para conferir essa última frase, a viva descrição da gaiola de ferro gradeada onde Lima-Vicente é conduzido para o manicômio:

É indescritível o que se sofre ali, assentado naquela espécie de solitária, pouco mais larga que a largura de um homem, cercado de ferro por todos os lados, com uma vigia gradeada, por onde se enxergam as caras curiosas dos transeuntes a procurarem descobrir quem é o doido que vai ali. A carriola, pesadona, arfa que nem uma nau antiga, no calçamento; sobe, desce, tomba pra aqui, tomba para ali; o pobre-diabo lá dentro, tudo liso, não tem onde se agarrar e bate com o corpo em todos os sentidos, de encontro às 
paredes de ferro; e, se o jogo da carruagem dá-lhe um impulso para frente, arrisca-se a ir de fuças de encontro à porta de praça-forte do carro-forte, a cair no vão que há entre o banco e ela, arriscando-se a partir as costelas [...]. Um suplício destes, a que não sujeita a polícia os mais repugnantes e desalmados criminosos, entretanto ela aplica a um desgraçado que teve a infelicidade de ensandecer, às vezes, por minutos...

Lima Barreto retomaria a narração dessa viagem cruel no conto "Como o 'Homem' chegou", dando-lhe um final sinistro: o suposto demente, um pobre astrônomo amador, é trazido na jaula de Manaus ao Rio de Janeiro e, no trajeto, devorado por abutres; é apenas o seu cadáver que chega ao hospício.

Barbárie e civilização costumam alternar-se ou variamente compor-se. O conluio não ocorre só no Brasil, em que pese aos que se comprazem em dar ao país o monopólio do atraso misturado com novidades postiças. A denúncia veio da Europa e está presente, apesar das diferenças de horizonte político, em Swift, em Schopenhauer, em Burckhardt, em Marx, em Dostoiévski, em Walter Benjamin, em Ortega y Gasset, em Simone Weil, em Brecht; e é um dos tópicos mais ardidos da crítica da cultura que escaparam aos horrores do nazismo, soube avaliar a tempo os do estalinismo, mas igualmente armou suas antenas para captar os signos de brutalidade, cinismo e eficiência técnica emitidos pela civilização de massas de tipo americano que prevaleceu no Ocidente a partir da Segunda Guerra.

A carriola de ferro onde enjaularam o pobre bêbado delirante levou-o aos trancos a um edifício de equilibradas linhas neoclássicas. Lima Barreto observou com justeza que a construção do hospício, terminada em 1852, moldou-se "ao gosto do pseudoclássico da Revolução e do Império Napoleônico". O historiador Pedro Calmon, que escreveu O Palácio da Praia Vermelha, nos informa que a planta do edifício reproduziu a da Maison Nationale de Charenton, matriz dos hospitais psiquiátricos franceses. "O seu arquiteto, Domingos Monteiro" - lembra ainda Lima Barreto - "foi discípulo da antiga Academia de Belas-Artes e certamente do arquiteto Grandjean de Montigny. É de aspecto frio, severo, solene, com pouco movimento nas massas arquitecturais. Custou naquela época cerca de mil e quinhentos contos".

A fachada é ampla, o fundo é proporcional e os remates são cuidadosos. Mas, se deslocarmos o olhar do nobre frontão e das janelas dispostas em perfeita simetria para o pátio da Secção Pinel, o quadro muda, torna-se negro:

Este pátio é a coisa mais horrível que se possa imaginar. Devido à pigmentação negra de uma grande parte dos doentes aí recolhidos, a imagem que se ficou dele, é que tudo é negro. O negro é a cor mais cortante, mais impressionante; e contemplando uma porção de corpos negros nus, faz ela que as outras se ofusquem no nosso pensamento. É uma luz negra sobre as coisas, na suposição de que, sob essa luz, o nosso olhar pudesse ver alguma coisa.

Em outra passagem, acena para o contraste com a natureza: "Não é mais o dia azulcobalto e o céu ofuscante, não é mais o negror da noite picado de estrelas palpitantes. É a treva absoluta, é toda ausência de luz...".

A imagem que tudo recobre é de uma grande abóbada de treva, de negro absoluto. As luzes do neoclassicismo trazido pela Missão francesa no tempo do rei queriam ser racionais e modernas, mas dentro do solene edifício que construíram reinaria uma treva absoluta onde deveria ser encerrada a desrazão do negro e do pobre.

$$
* * *
$$

Havia uma chácara no fundo do hospício. As árvores eram muito antigas, pois diziam que D. João VI, passeando pela praia, já as encontrara taludas. 
Vicente e outro interno, Misael, que se fizera seu amigo, gostavam de caminhar pelas amendoeiras e por entre as moitas de bambus. $\mathrm{O}$ narrador imagina que aquelas velhas árvores outrora "destinavam-se a uma remansosa estação de recreio, teriam assistido festas de junho, bulhentas de foguetes e outros fogos, e iluminadas por fogueiras de cultos esquecidos". Mas os anos tinham passado, e agora as mesmas grandes jaqueiras, mangueiras e laranjeiras deviam contemplar a miséria de uma humanidade, "aquela que nos faz outro, aquela que parece querer mostrar que não somos verdadeiramente nada...”.

O narrador lança o olhar para o seu passado. O sonho de Vicente, nunca realizado, fora ter um lar, uma casa, sempre a mesma e capaz de transmitir aos moradores as lembranças dos pais e avós, aquelas memórias que criam em cada filho e neto "raízes fortes no tempo e no espaço" e o sentimento de ser um "elo de uma cadeia infinita".

Uma horta, um pomar com grandes jaqueiras, laranjeiras, abacateiros, sempre foi o meu sonho; e estavam ali aqueles restos de uma grande chácara, com árvores de mais de meio século de existência, maltratadas, abandonadas, talvez, de toda contemplação sonhadora de olhos humanos, mas que ainda assim davam prazer, consolavam aquele sombrio lugar de dor e de angústia.

Por baixo das árvores os doentes descansavam. O cenário tinha mudado, e a natureza, que no delírio de Brás Cubas se mostrava indiferente ao destino dos homens, aparece aos olhos de Vicente como sombra compassiva. "Voltamos pelo mesmo caminho. Olhei o céu tranqüilo, doce, de um azul muito fino. Não se via o sol, que descambava pelas nossas costas".

Lima Barreto teria amado estes versos de Rosalía de Castro, cristãmente pagãos no seu amor pelos desvalidos enlaçado ao culto da divina Natureza:

Natureza formosa, eternamente a mesma, dizei aos loucos, aos mortais dizei que eles não perecerão. ${ }^{6}$

\footnotetext{
${ }^{6}$ Rosalía de Castro, "Follas Novas", 1880, in Rosalía de Castro, Poesia, tradução de Ecléa Bosi, 2. ed., São Paulo, Brasiliense, 1987, p. 100.
} 